\title{
THE CHANGE IN WORLD PRICE AND EXPORT TAX OF CRUDE PALM OIL AND THEIR IMPACT ON THE ECONOMY AND WELFARE IN INDONESIA: USING A COMPUTABLE GENERAL EQUILIBRIUM (CGE) MODEL
}

\author{
Sadik Ikhsan ${ }^{1,2 *}$, Ratya Anindita ${ }^{1}$, Nuhfil Hanani ${ }^{1}$, Djoko Koestiono ${ }^{1}$ \\ ${ }^{1}$ Faculty of Agriculture, University of Brawijaya, Malang, Indonesia \\ ${ }^{2}$ Faculty of Agriculture, University of Lambung Mangkurat, Banjarbaru, Indonesia
}

*E-mail: sadikikhsan@yahoo.com.sg

\begin{abstract}
The research aimed to analyze the impact of change in world price and export tax of crude palm oil on the export and domestic production performance of some selected economic sectors, as well as households' welfare in Indonesia. The analyses were carried out by a Computable General Equilibrium (CGE) static model with data taken from Indonesian Social Accounting Matrix (SAM) 2008. The results showed that the increase in world price accompanied by the increase in export tax of crude palm oil and rupiah depreciation have positive impact on the export and domestic production performance of palm oil manufacture sectors and other related economic sectors. Prevailing progressive tax on crued palm oil export does not have negative impact resulted in decreasing palm oil export because export unit price received by producers remains higher than the price at baseline. Due to the increasing of export performance and domestic production, production sectors have economic ability to meet the demands of paying higher value-added upon primary production factors owned by households so that households' factor income increase and eventually, it leads households' welfare increase as well.
\end{abstract}

\section{KEY WORDS}

Social accounting matrix, computable general equilibrium, crude palm oil, export taxes, exports, domestic production, welfare.

Indonesia obtains huge economical benefits from oil palm plantations and the palm oil manufacture. The share of Indonesian exports of crude palm oil in 2010 as $46.68 \%$ which was along with Malaysian export as $42.21 \%$ (FAOStat-Agriculture, 2012) had dominated the world market. The contribution of foreign exchange from the exports in 2014 reached US\$ $17,464.9$ million or 13,4 percent of Indonesia export total value (Indonesian Central Beureau of Statistics, 2015). In addition, oil palm plantations are labor intensive due to land area stretching many hectares and the lack of mechanization, especially in planting, harvesting and fruit gathering, offering solutions to unemployment problems in Indonesia. Finally, the crude palm oil is a basic material for palm oil downstream manufactures which processes it into high value-added derivative products. The adequacy of supply availability determines the development of domestic palm oil downstream manufactures in Indonesia.

High demands of crude palm oil caused by population growth, raising of gross domestic income of importing countries, shifting of consumer preferences due to health concerns, economical prices, as well as the growing of various derivative products, including biofuel, lead to increase world prices of crude palm oil. High world prices provide incentives to producers offering their products to export markets.

Exports of crude palm oil should be controlled to ensure that its supply is sufficient in the country. One of the trade instruments used by Indonesia for this purpose is export tax. The amount of export tax is formulated increase progressively following world prices of crude palm oil represented by the Export Reference Price (ERP) (Table 1). ERP is set through the regulation of the Minister of Trade based on weighted average price referring to c.i.f. Rotterdam, Malaysian Derivative Exchange (MDEX), and Indonesia Stock Exchange in the 
last one month before prevailing ERP. ERP is valid for one month only and then is set a new ERP for the next month.

Table 1 - The amount of export tax on crude palm oil in the range of ERP

\begin{tabular}{ccc}
\hline No. & ERP range $($ US $\$$ /ton $)$ & Export tax $(\%)$ \\
\hline \hline 1. & ERP $\leq 700$ & 0.0 \\
2. & $700<\mathrm{ERP} \leq 750$ & 1.5 \\
3. & $750<\mathrm{ERP} \leq 800$ & 3.0 \\
4. & $800<\mathrm{ERP} \leq 850$ & 4.5 \\
5. & $850<\mathrm{ERP} \leq 900$ & 6.0 \\
6. & $900<\mathrm{ERP} \leq 950$ & 7.5 \\
7. & $950<\mathrm{ERP} \leq 1000$ & 10.0 \\
8. & $1000<\mathrm{ERP} \leq 1050$ & 12.5 \\
9. & $1050<\mathrm{ERP} \leq 1100$ & 15.0 \\
10. & $1100<\mathrm{ERP} \leq 1150$ & 17.5 \\
\hline
\end{tabular}

Source: The Regulation of Ministry of Finance No. 159/PMK.011/2008 at October 30th, 2008.

Changes in world price of crude palm oil led to changes in ERP, export taxes prevailed and export unit price received by producers. As a consequence of implementation of export tax, export unit price received by producers lessened form the world price as much as that tax (Anindita \& Reed, 2008). The changes will impact directly on domestic production of oil palm plantations and palm oil manufacture, transformation of that product to enter either export or domestic markets, and households' welfare. Novindra's research (2011), using a partial approach, showed that the simulation of 50 percent increasing export tax of crude palm oil led to its export price received by producers, reduced by 1.106 percent and succeeded in reducing the export of crude palm oil as 0.031 percent which was diverted to meet the domestic demands for downstream manufactures using basic materials of crude palm oil. Decreasing domestic crude palm oil price was a disincentive for producers responded by reducing decreasing domestic production of crude palm oil amounted to 0.024 percent.

In a partial approach, the adjustment of supply and demand on a single commodity to achieve an equilibrium is affected only by the price of that commodity. Prices of other commodities are considered constant - or it is thought to be unrelated to commodity. However, in the real world, different results are obtained. In the general equilibrium approach referring to the Walras' Law, a framework is made to link all markets which therefore interact among industries, factor resources, and institutions. The adjustments that take place in one market due to price change to find a new equilibrium, will interact simultaneously other markets and generate market feedbacks (Vargas et al, 1999) until it forms a new general equilibrium covering all markets.

This study aimed to analyse the impact of world price changes and export tax of crude palm oil on the economy sectors and households' welfare in Indonesia by using Computable General Equilibrium (CGE) static approach.

\section{THEORETICAL REVIEW}

The impact of Export Tax on Production, Consumption, and Welfare. Before tax is applied, the relative price of commodities $q_{1}$ and $q_{2}$ prevailing in the country was $\mathrm{p}=\frac{\mathrm{p}_{1}}{\mathrm{p}_{2}}=\frac{\mathrm{p}_{1}^{*}}{\mathrm{p}_{2}{ }^{*}}=\mathrm{p}^{*}$ or equal to the world price. After prevailing ad valorem tax on the export commodity, $q_{1}$ amounted te so that its price is $p_{1}=p_{1}{ }^{*}(1-t e)$ and the relative prices of commodities distorted into $\mathrm{p}^{\top}=\frac{\mathrm{p}_{1}^{*}(1-\mathrm{te})}{\mathrm{p}_{2}{ }^{*}}=\mathrm{p}^{*}(1-\mathrm{te})$ that was less than the world relative prices of commodities, $\mathrm{p}^{*}$.

Graphic illustration of the impact of the export tax implementation on the equilibrium of production and consumption is shown in Figure 1. On the free trade with the world relative 
prices of commodities, $p^{*}$, levels of production and consumption respectively found in $Q_{1}$ and $\mathrm{C}_{1}$ with the welfare lies in the community indifference curve, $\mathrm{I}_{1}$. As a result of prevailed export tax, relative price of commodity in the domestic market, $p^{\top}=p^{*}(1-$ te $)$ is less than $p^{*}$ and, therefore, slope of production possibilities frontier (PPF) and community indifference curve become more gently sloping so that the domestic production moves from $Q_{1}$ to $Q_{T}(=$ production decreased) and community consumption moves from $\mathrm{C}_{1}$ to $\mathrm{C}_{\mathrm{T}}$ (= consumption decreased). . The production point of $\mathrm{Q}_{t}$ and consumption point of $\mathrm{C}_{t}$ are intersected both by the line of domestic relative prices, $p^{\top}$ (after prevailing export taxes) and the line of world relative prices, $p^{*}$ indicates that both of them cannot be separated from $p^{\top}$ and $p^{*}$.

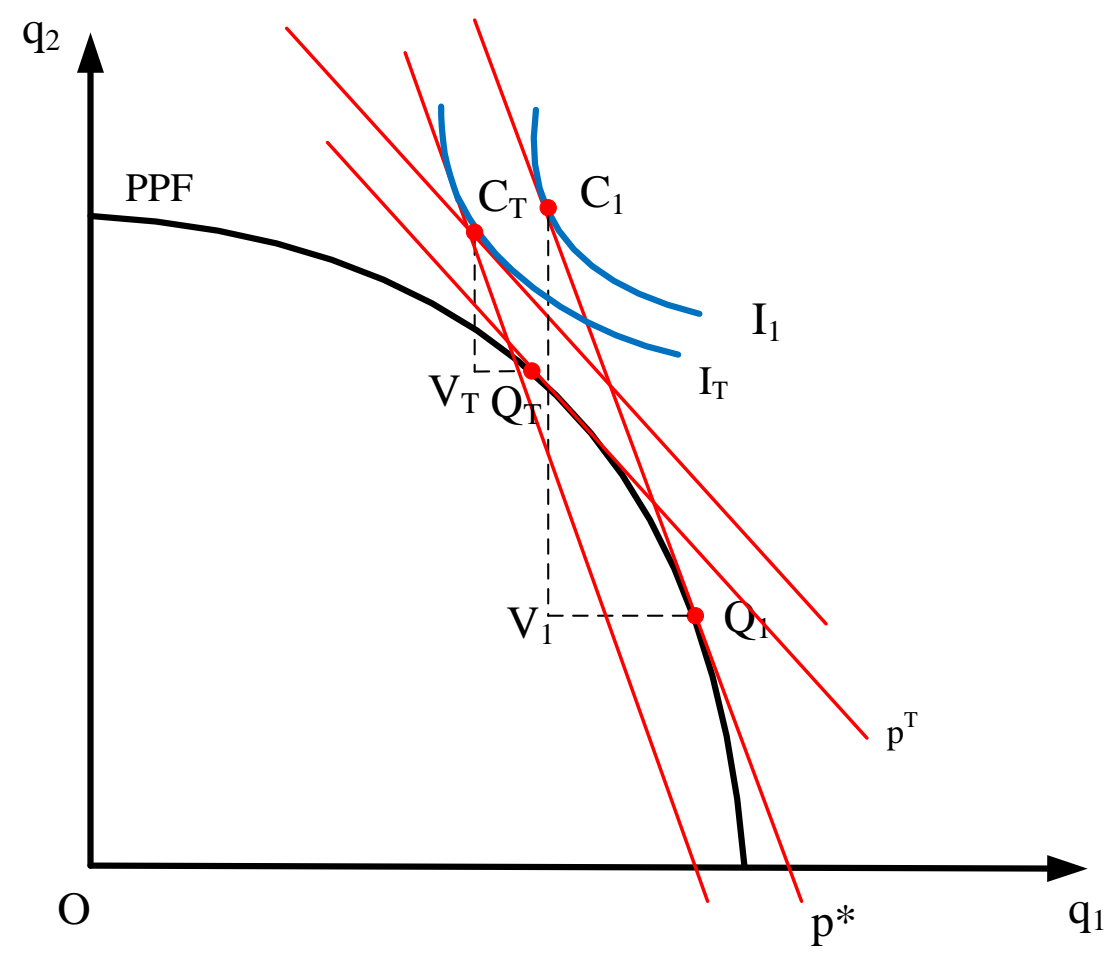

Figure 1 - Implementation export tax causes $\mathrm{p}^{*} \rightarrow \mathrm{pT}$

The shift from $Q_{1}$ to $Q_{T}$ (production decreased) and from $C_{1}$ to $C_{T}$ (consumption decreased) also cause excess demand, $E D\left(E D_{1}=q_{1 c}-q_{1 Q}\right.$ for commodities of $q_{1}$, and $E D_{2}$ $=q_{2 C}-q_{2 Q}$ for commodities of $q_{2}$ ) decrease. According to the trade balance condition, ED can be fulfilled through the trade i.e. exports and imports at the world relative prices of commodities, $\mathrm{p}^{*}$. Therefore, the impact of prevailed export tax is reduced trade both in volume and in value.

The equilibrium of society consumption at the point of $\mathrm{C}_{\mathrm{T}}$ found in indifference curve of $I_{T}$ which is lower than $I_{1}$ indicates that after prevailing export tax, society welfare has decreased. According to Salvatore (1995), the welfare decrease comes from two causes: (1) the economy does not produce at the point of maximizing profit on the world prices -or known as loss due to the distortion of production; and (2) the consumption which can be conducted not on the highest indifference curve that maximizes the welfare on the world prices - or known as losses due to the distortion of consumption.

Armington Assumption on Commodities. Final commodities consumed by households, firms, and government consist of domestic commodities (i.e. commodities which are produced inside the country) and import commodities. Armington (1969) assumed that in the view of the consumer, those commodities had differences based on the country of origin, although they were produced in similar production technology. Both are imperfect substitutable and to be aggregated into composite final commodities (Figure 2) by the CES (constant elasticity of substitution) production function, 


$$
Q_{c}=\gamma\left(\delta \mathrm{Q}_{\mathrm{m}}^{-\eta_{1}}+(1-\delta) Q_{d}^{-\eta_{i}}\right)^{-\frac{1}{\eta_{i}}}
$$

where: $Q_{c}, Q_{m}, Q_{d}$ - composite commodity, import commodity, and domestic commodity (in sequence);

$\gamma$ - scalling parameter;

$\delta$ - share parameter;

$\eta$ - substitution parameter, $\eta=\frac{(\sigma-1)}{\sigma}, \eta \leq 1$;

$\sigma$ - elasticity of substitution.

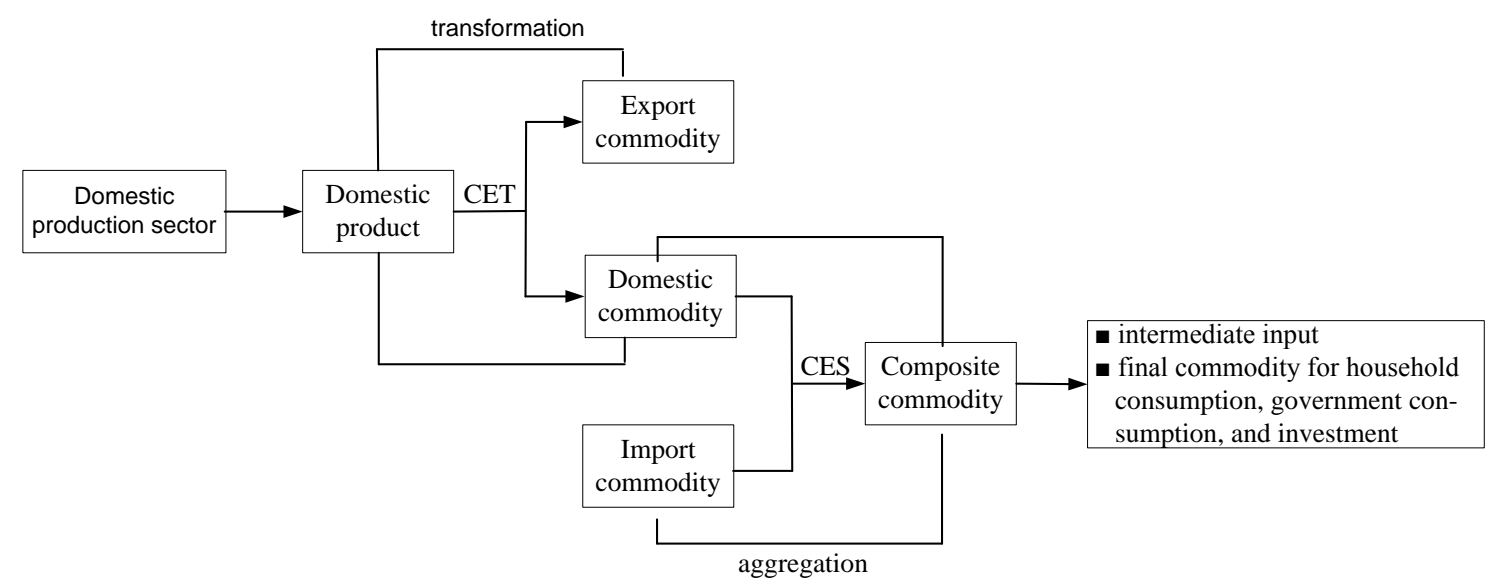

Figure 2 - The aggregation between domestic and import commodity to become composite commodity and the transformation of domestic product into domestic and export commodity

Intermediate inputs which are used in production activities also consist of domestic intermediate-inputs and import intermediate inputs. They are imperfect substitutable and are aggregated based on the Armington assumption by the CES production function to become composite intermediate inputs.

Armington assumption is a solution to cross hauling matter in trade statistics. Cross hauling refers to a kind of commodity that are simultaneously shipped in opposite directions between two countries over the same route and in a certain time duration.

By using the same Armington assumption, the final commodities produced by domestic production sectors are transformed according to its market destination to be domestic and export commodities (Figure 2) by using CET (constant elasticity of transformation) function,

$$
Q_{p}=\theta\left(\xi \mathrm{Q}_{\mathrm{e}}{ }^{\Phi_{\mathrm{i}}}+\left(1-\xi \mathrm{Q}_{\mathrm{d}} \Phi^{\Phi_{\mathrm{i}}}\right)^{\frac{1}{\Phi_{i}}}\right.
$$

where:

$\mathrm{Q}_{\mathrm{p}}, \mathrm{Q}_{\mathrm{e}}, \mathrm{Q}_{\mathrm{d}} \quad$ commodity produced by domestic production sector, export commodity, and domestic commodity (in sequence);

$\theta$ - scalling parameter;

$\xi$ - share parameter;

$\Phi$ - transformation parameter, $\Phi=\frac{(\psi+1)}{\psi}, \Phi \geq 1$;

$\Psi$ - elasticity of transformasion.

Production Structure. Production activities in CGE model are formulated in hierarchical structure, two-nested stage, namely bottom stage production activities and top stage 
production activities (Figure 3). Bottom stage production activities use primary factors of production consisting of labor and capital as inputs to produce outputs namely value-added or composite primary factors. The technology of production in this stage is specified by a CES function. Labor itself is a CES aggregation of skilled labors and unskilled labors. Moreover, top stage production activites use inputs which are value-added made by bottom stage production activity and composite intermediate inputs to produce the final products. The production technology at the top stage is specified as a Leontief function.

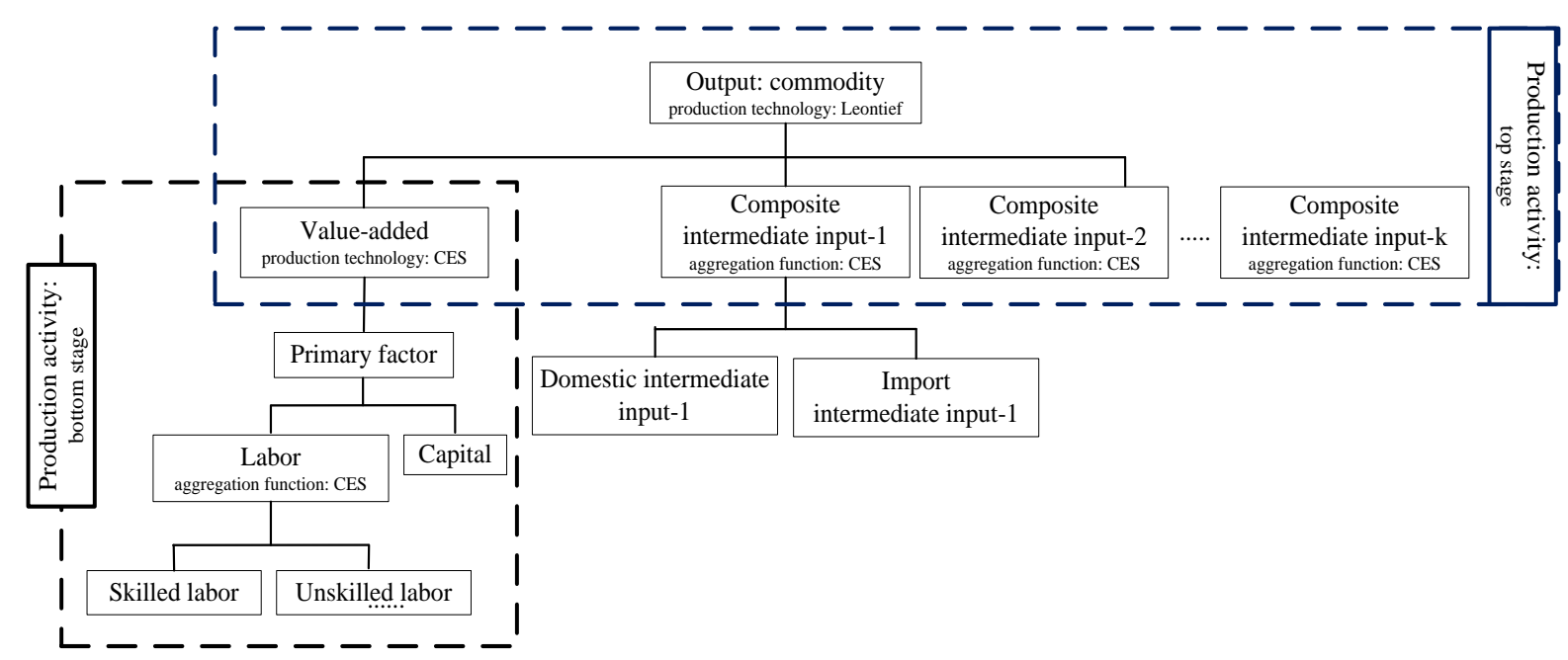

Figure 3 - Production activities structure-hierarchical or two-nested stage: bottom stage and top stage

Welfare. Prevailing policies such as crude palm oil export tax which impacts on the economy changes causes the social welfare of agencies in the economy becomes better-off or worse-off. Hicks in 1943 proposed monetary measurement which allow the consumer freedom of choice in responding to a changing economic environment, namely equivalent variation (EV) and compensasting variation (CV) to represent the welfare changes (Just et al, 2004). EV and CV are formulated based on indirect money metric utility function, $\mu(\mathbf{q} ; \mathbf{p}, m)$. It refers to the income needed by consumer at a prices of $\mathbf{p}$ to be as well off as one would be facing prices $\mathbf{q}$ and having income $\mathrm{m}$. In mathematics. Varian (1992) defines EV and CV as follows:

$$
\begin{aligned}
& E V=\mu\left(\underline{\mathbf{p}}^{0} ; \underline{\mathbf{p}}^{1}, \mathrm{~m}^{1}\right)-\mu\left(\underline{\mathbf{p}}^{0} ; \mathbf{p}^{0}, \mathrm{~m}^{0}\right)=\mu\left(\mathbf{p}^{0} ; \mathbf{p}^{1}, \mathrm{~m}^{1}\right)-\mathrm{m}^{0} \\
& \mathrm{CV}=\mu\left(\mathbf{p}^{1} ; \underline{\mathbf{p}}^{1}, \mathrm{~m}^{1}\right)-\mu\left(\mathbf{p}^{1} ; \underline{\mathbf{p}}^{0}, \mathrm{~m}^{0}\right)=\mathrm{m}^{1}-\mu\left(\mathbf{p}^{1} ; \underline{\mathbf{p}}^{0}, \mathrm{~m}^{0}\right)
\end{aligned}
$$

Where:

$\underline{\underline{p}}^{0} \quad$ vector of prevailing prices (or old prices);

$\mathbf{p}^{1} \quad$ vector of new prices;

$\mathrm{m}^{0} \quad$ old income;

$\mathrm{m}^{1} \quad$ new income.

If a policy is a changing of prices from $\mathbf{p}^{0}$ into $\underline{\mathbf{p}}^{1}$ which leads to the increasing of new utility of the consumer to a higher position, then EV uses the prevailed prices, $\mathbf{p}^{0}$ as a base for evaluating the amount of income change needed by consumers to obtain equivalent utilities as the new utilities at $\left(\mathbf{p}^{1}, \mathrm{~m}^{1}\right)$. Meanwhile, CV uses new price, $\mathbf{p}^{1}$ as a base for determining the income change to compensate the consumers for the price changes and place them to the old utilities position $\left(\mathbf{p}^{0}, \mathrm{~m}^{0}\right)$.

Practically, Just et al (2004) interprets CV and EV as willingness to pay (WTP) and willingness to accept (WTA). CV is amount of income taken from (or vice versa) consumers after the changes of the price and/or income to restore consumer welfare levels to its original position. In the same way, EV is amount of income given to (or vice versa) consumers as a 
compensation to place the consumers into the same welfare levels as the changes due to the changes of price and/or the changes of income.

\section{MATERIALS AND METHODS}

CGE static models used in this study was constructed by referring to a general model developed by Hosoe et al (2015) and Lofgren et al (2002) with data obtained from Indonesia Social Accounting Matrix (SAM) and Input-Output Table 2008 (Indonesian Central Beureau of Statistics, 2010). Aggregation and disaggregation on SAM sectors reduced the dimensions of SAM matrix from $105 \times 105$ to $81 \times 81$ with four classifications of households consisting of farm-worker households, agricultural-entrepreneur households, rural non-agricultural households, and urban non-agricultural households.

In the CGE statics model, the behavior of producers represented through the production sectors is assumed to maximize profit with respect to production technology. Each sector produces domestic product which is transformed folowing CET function into domestic commodity and export commodity. Households as comsumers that maximize utilities specified as a Geary-Stone function with respect to their budget constraint. The maximization of Stone-Geary utility function generates a demand function of Linear Expenditure System (LES). Final commodities consumed by households and intermediate commodities used by production sectors are composite commodities agregated from domestic comodities and import commodities with the CES function based on Armington assumption. Modelling and analizing CGE statics are conducted with GAMS/MPSGE program. The GAMS/MPSGE program has some advantages. It has routines to process calibration and specification of the CES and CET function. The calibration process, including replication check to validate the benchmarks equilibrium is performed automatically by MPSGE.

Analysis of impact of changes in world prices and export tax of crude palm oil on the performance of domestic product and export of economy sectors as well as household welfare was conducted by before-after pairwise comparison between baseline and counterfactual. Baseline is set on ERP $=$ US\$ 925.-/ton; export tax (te) $=7.5 \%$, and exchange rate $(E X R)=$ IDR 9,466.-/US\$, meanwhile counterfactuals are simulated as follows:

\begin{tabular}{|c|c|c|c|c|c|}
\hline $\begin{array}{l}\text { Scenario-1 } \\
\text { Scenario-2 } \\
\text { Scenario-3 } \\
\text { Scenario-1.1 } \\
\text { Scenario-1.2 } \\
\text { Scenario-2.1 } \\
\text { Scenario-2.2 }\end{array}$ & $\begin{array}{l}: E R P=U S \$ \\
: E R P=U S \$ \\
: E R P=\text { US\$ } \\
: E R P=U S \$ \\
: E R P=U S \$ \\
: E R P=U S \$ \\
: E R P=U S \$\end{array}$ & $\begin{array}{l}\text { 700.-/ton, } \\
\text { 1,025.-/ton, } \\
1,125 .- \text { ton, } \\
700 .- \text { ton, } \\
\text { 700.-/ton, } \\
\text { 1,025.-/ton, } \\
\text { 1,025.-/ton, }\end{array}$ & $\begin{array}{l}\text { te }= \\
\text { te }= \\
\text { te }= \\
\text { te }= \\
\text { te }= \\
\text { te }= \\
\text { te }=\end{array}$ & $\begin{array}{ll}00.0 \%, & \text { EXR }=\text { IDR } \\
12.5 \%, & \text { EXR }=\text { IDR } \\
17.5 \%, & \text { EXR }=\text { IDR } \\
00.0 \%, & \text { EXR }=\text { IDR } \\
00.0 \%, & \text { EXR }=\text { IDR } \\
12.5 \%, & \text { EXR }=\text { IDR } \\
12.5 \%, & \text { EXR }=\text { IDR }\end{array}$ & $\begin{array}{l}\text { 9,466.-/US\$; } \\
\text { 9,466.-/US\$; } \\
\text { 9,466.-/US\$; } \\
\text { 11,000.-/US\$; } \\
\text { 13,000.-/US\$; } \\
\text { 11,000.-/US\$; } \\
\text { 13,000./US\$; }\end{array}$ \\
\hline
\end{tabular}

Where:

ERP export reference price;

IDR Indonesian rupiah;

te export tax; and

EXR rupiah exchange rate.

\section{RESULT AND DISCUSSION}

The connection of Input-Output between Oil Palm Plantation Sector and Palm Oil Manufacture Sector. The connection of input-output between oil palm plantation and palm oil manufacture is shown in Figure 4. Oil palm plantation sector produces output worth of IDR $83,010.00$ billions. Most of them, i.e. IDR $67,026.33$ billions $(80.74 \%)$ is absorbed by palm oil manufacture sector as an intermediate input. Meanwhile, the rest used by the oil palm plantation sector itself was IDR $3,912.51$ billions $(4.71 \%)$ and other sectors were IDR 
$11,700.87$ billions $(14,10 \%)$ as intermediate input, and is being exported around IDR 370.28 billions $(0.45 \%)$. Most of intermediate input used by oil palm plantation sector was fertilizer and pesticide amounting IDR 15, 956.1 billions (48\%).

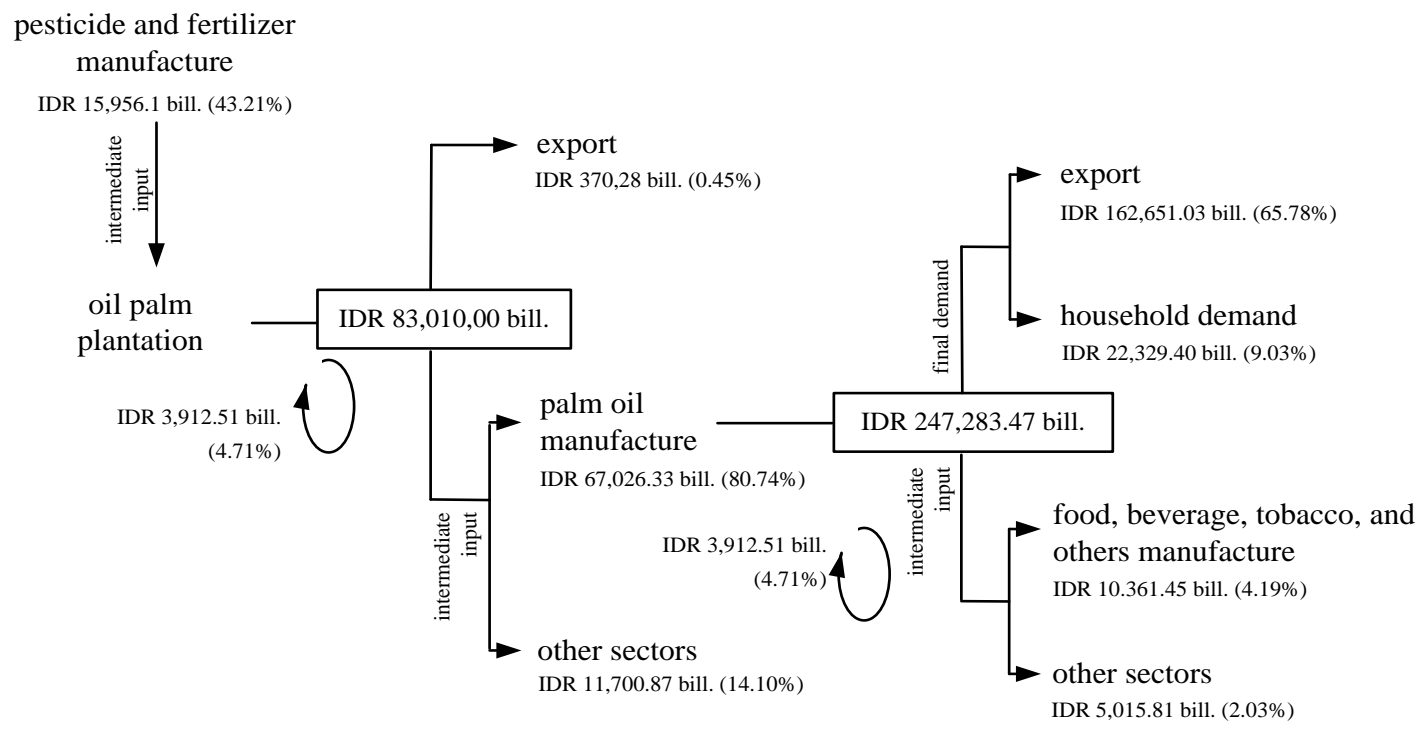

Figure 4 - The connection of input-output among sectors associated with oil palm plantation and palm oil manufacture

Palm oil industry generates products worthing IDR 247,283.47 billions. Most of products amounting IDR $162,651.03$ billions $(65.78 \%)$ offered to the export market. The rest of it amounting IDR $22,329.40$ billions (9.03\%) to meet final demand of households and amounting IDR 3,912.51 billion (18.98\%), IDR 10,361.45 billions (4.19\%), and IDR 5,015.81 billions $(2.03 \%)$, respectively, used by palm oil manufacture itself; food, beverages, tobacco (and others) manufacture; and other manufactures as intermediate input.

The impact of ERP Changes and Export Tax of Crude Palm Oil on the Domestic Productions and Exports. Increasing ERP of crude palm oil has direct and positive impacts on palm oil export. As shown in Tabel 2, higher export of palm oil was associated with higher ERP of crude palm oil. Progressive increase of export tax of crude palm oil along with increase of world prices of crude palm oil is suggested resulting negative impact. However, in that case, it is not causing lower export unit price (pe) received by producers due to greater percentage of increasing ERP than percentage of increase in export tax. Prevailing export tax only reduces some price received by producers but not providing disincentive to producers offering their product to export markets.

Increase in ERP of crude palm oil impacts indirectly and negatively on export of fresh fruit bunches produced by oil palm plantation sector. This fact is consistent with the idea of not exporting commodities in the form of the feedstock or raw materials. The comodities should be proccessed through manufacture to produce downstream products level I and II which provide higher value-added to the commodities (National Income Policy Center, Fiscal Policy Agency, 2011). In addition, the exports of food, beverages and tobacco also decrease. Yet, due to rising domestic production of food, beverages and tobacco, decrease in their export might indicate products are aimed mostly to fulfill domestic market demands.

The depreciation of Indonesian rupiah against US\$ generally gives a positive impact on export of commodities produced by oil palm plantation, palm oil manufacture, and food, beverages, and tobacco manufacture sector (Table 3). Depreciation causes export unit price increased after being converted into Indonesia rupiah. At ERP US\$ 700.-/ton (scenario 1.1 and 1.2), exports of these commodities increase, except exports of palm oil which decrease. Nevertheless, decrease in export of palm oil occurs due to its world price which is lower than its price on the baseline (US\$ 925.-/ton). 
Table 2 - Changes in domestic production and export of selected sectors due to the effect of ERP changes and export tax of crude palm oil

\begin{tabular}{|c|c|c|c|c|}
\hline & \multirow{2}{*}{ Baseline } & \multicolumn{3}{|c|}{ Scenario } \\
\hline & & 1 & 2 & 3 \\
\hline ERP (US\$/ton) & 925 & 700 & 1,025 & 1,125 \\
\hline te $(\%)$ & 7.5 & 0.0 & 12.5 & 17.5 \\
\hline EXR (IDR/US\$) & 9,466 & 9,466 & 9,466 & 9,466 \\
\hline pe (indeks) & 0.925 & 0.757 & 0.969 & 1.004 \\
\hline Domestic productions & $\begin{array}{l}\text { Actual Value } \\
\text { (IDR bill.) }\end{array}$ & \multicolumn{3}{|c|}{ Changes percentage from baseline } \\
\hline \multirow{4}{*}{$\begin{array}{l}\text { Oil palm plantation sector } \\
\text { Palm oil manufacture sector } \\
\text { Food, beverage, tobacco (and others) } \\
\text { manufacture sector } \\
\text { Fertilizers and pesticides manufacture sector }\end{array}$} & $83,010.00$ & 10.714 & -3.571 & -7.143 \\
\hline & $247,283.47$ & 1.802 & -0.180 & -0.360 \\
\hline & $988,275.16$ & -0.612 & 0.240 & 0.479 \\
\hline & $65,367.99$ & -0.926 & 0.000 & 0.000 \\
\hline \multicolumn{5}{|l|}{ Exports } \\
\hline \multirow{3}{*}{$\begin{array}{l}\text { Oil palm plantation sector } \\
\text { Palm oil manufacture sector } \\
\text { Food, beverage, tobacco (and others) } \\
\text { manufacture sector }\end{array}$} & 370.28 & 28.828 & -5.936 & -10.167 \\
\hline & $162,651.03$ & -25.954 & 11.145 & 21.832 \\
\hline & $43,933.86$ & 1.087 & -0.408 & -0.951 \\
\hline
\end{tabular}

Note: ERP is export reference price; te is export tax; EXR is exchange rate; pe is export unit price (after tax) received by producers, $p e=$ pwe. $(1-$ te $) . E X R$ - namely, normalizing price index.

Along with the increase of world prices and export tax of crude palm oil, as shown in Table 2, at scenario 2 domestic production of oil palm plantation sector and palm oil manufacture sector decrease. However, this negative impact, especially on the domestic production of palm oil manufacture sector, can be compensated by rupiah depreciation at IDR11,000.-/US\$ and IDR 13,000.-/US\$, respectively at scenario 2.1 and 2.2 (Table 3). Higher depreciates of Indonesia rupiah generate higher domestic production of oil palm plantation sector. Moreover, decrease in domestic production of oil palm plantation is not only caused by indirect negative impact of highly progressive export tax, but also by high cost of production. High cost of production of oil palm plantation sector is due to demands of paying higher value-added unit on the use of primary factors to households as factor owner.

Table 3 - Changes in domestic production and exports of selected sectors due to effect of rupiah depreciation

\begin{tabular}{llllll}
\hline & \multirow{2}{*}{ Baseline } & \multicolumn{4}{c}{ Scenario } \\
\cline { 3 - 5 } & & 1.1 & 1.2 & 2.1 & 2.2 \\
\hline \hline ERP (US\$/ton) & 925 & 700 & 700 & 1,025 & 1,025 \\
te (\%) & 7.5 & 0.0 & 0.0 & 12.5 & 12.5 \\
EXR (IDR/US\$) & 9,466 & 11,000 & 13,000 & 11,000 & 13,000 \\
\hline Domestic Production & $\begin{array}{l}\text { Actual value } \\
\text { (billions IDR) }\end{array}$ & \multicolumn{2}{c}{ Changes percentage from baseline } \\
\hline \hline Oil palm plantation sector & $83,010.00$ & 3.571 & 10.714 & -3.571 & -3.571 \\
Palm oil manufacture sector & $247,283.47$ & 5.946 & 10.631 & 4.144 & 8.649 \\
Food, beverage, tobacco (and others) & $988,275.16$ & 0.000 & 0.612 & 0.799 & 1.305 \\
manufacture sector & & & & \\
Fertilizers and pesticides manufacture & $65,367.99$ & 6.481 & 6.667 & 6.481 & 15.741 \\
sector & & & & & \\
\hline Export & 370.28 & 45.724 & 66.999 & 6.979 & 23.721 \\
\hline \hline $\begin{array}{l}\text { Oil palm plantation sector } \\
\text { Palm oil manufacture sector }\end{array}$ & $162,651.03$ & -18.473 & -10.229 & 22.290 & 35.267 \\
$\begin{array}{l}\text { Food, beverage, tobacco (and others) } \\
\text { manufacture sector }\end{array}$ & $43,933.86$ & 16.168 & 35.734 & 14.402 & 33.967 \\
\hline
\end{tabular}

The impact of ERP and Export Tax of Crude Palm Oil Change to Households' Welfare. Households' welfare increased following increasing ERP of crued palm oil and the rupiah depreciation (Table 4). At ERP US\$ 700.-/ton, without an export tax, and the exchange rate Rp 9,466.-/US\$, households' welfare decreases. Increasing ERP of crude palm oil to IDR 1,025.-/ton and rupiah depreciation at IDR11,000.-/US\$ and IDR 13,000.-/US\$ (scenario 2.1 
and 2.2) cause producers' revenue that gain the positive impact from these changes increase after being converted into rupiah. Progressive increasing export tax along with increasing ERP of crude palm oil does not significantly give a negative effect on export value received by producers. Therefore, producers have ability to meet demands for paying higher value-added on primary factors used in production activities. The payment on value-added of the primary factors is households' factor income. Higher value-added of primary factors paid by sectors causes increasing factor income received by household and, ultimately increasing households' welfare.

Table 4 - Changes in households' welfare due to the effect of changes in ERP and export tax of crude palm oil and the depreciation of rupiah

\begin{tabular}{|c|c|c|c|c|c|c|c|}
\hline & \multirow{2}{*}{ Baseline } & \multicolumn{6}{|c|}{ Scenario } \\
\hline & & 1 & 1.1 & 1.2 & 2 & 2.1 & 2.2 \\
\hline ERP(US\$/ton) & 925 & 700 & 700 & 700 & 1,025 & 1,025 & 1,025 \\
\hline te $(\%)$ & 7.5 & 0.0 & 0.0 & 0.0 & 12.5 & 12.5 & 12.5 \\
\hline $\operatorname{EXR}(\mathrm{Rp} / \mathrm{US} \$)$ & 9,466 & 9,466 & 11,000 & 13,000 & 9,466 & 11,000 & 13,000 \\
\hline Welfare & $\begin{array}{l}\text { Actual value } \\
\text { (billions IDR) }\end{array}$ & \multicolumn{6}{|c|}{ Percentage changes from baseline } \\
\hline Farm-worker households & $176,551.43$ & -1.176 & 2.941 & 7.647 & 0.000 & 4.118 & 8.824 \\
\hline $\begin{array}{l}\text { Agricultural-entrepreneur } \\
\text { households }\end{array}$ & $730,442.47$ & -0.565 & 3.390 & 7.910 & 0.565 & 4.520 & 8.475 \\
\hline Rural non-agriculture households & $1,134,739.53$ & -0.505 & 3.182 & 7.071 & 0.505 & 4.040 & 7.576 \\
\hline Urban non-agriculture households & $1,781,466.50$ & -0.515 & 3.093 & 6.701 & 0.515 & 4.124 & 7.732 \\
\hline
\end{tabular}

\section{CONCLUSION}

The increase of the world price of crude palm oil gives a direct and positive impact on the exports of palm oil. Higher crude palm oil world price generate higher export of crude palm oil increases. The prevailing of progressive export tax does not cause the performance of palm oil exports decreases. However, the export of products from oil palm plantation sector and from food, beverages and tobacco manufature sector decrease. Domestic production from oil palm plantation and palm oil manufacture sector also decrease; while the domestic production from food, beverages and tobacco manufacture sector, as well as from fertilizer and pesticide manufacture sector increase. However, depreciation of rupiah increases domestic production of palm oil. Depreciation generally has positive effects on export performance due to rising export price received by producers after being converted into rupiah. The increasing of this export value encourages domestic production performance to increase. Therefore, the production sector has the ability to meet the demands for paying higher value-added on primary production factor. The higher value-added on primary production factor causes the factor income received by households as the factor owner increases and, ultimately, households' welfare increase.

\section{REFERENCES}

1. Anindita, R. \& Reed, M.R. 2008. Bisnis dan Perdagangan Internasional. Andi, Yogyakarta

2. Anindita, R. \& Sayaka, B. 2003. Economic-wide Modelling. Jurnal Agrise, 2 (1), 8-15.

3. Armington, P.S. 1969. A Theory of Demand for Products Distinguished by Place of Production. International Monetary Fund Staff Papers, 16 (5), 159-178.

4. Arrow, K.J., Chenery, H.B., Minhas, B.S. \& Solow, R.M. 1961. Capital-Labor Substitution and Economic Efficiency. The Review of Economics and Statistics, 43(3), 225-250.

5. Haryono, D. 2008. Dampak Industrialisasi Pertanian terhadap Kinerja Sektor Pertanian dan Kemiskinan Perdesaan di Indonesia. PhD Dissertation. Bogor Agricultural University, Bogor. Unpublished.

6. Hosoe N., Gasawa, K., \& Hashimoto, H. 2015. Textbook of Computable General Equilibrium Modeling. Programming and Simulations. Palgrave Macmillan, Hampshire. 
7. Indonesian Central Beureau of Statistics. 2010. Sistem Neraca Sosial Ekonomi 2008. Indonesian Central Beureau of Statistics, Jakarta.

8. Indonesian Central Beureau of Statistics. 2010. Tabel Input Output Indonesia (updating) 2008. Indonesian Central Beureau of Statistics, Jakarta.

9. Just, R.E., Hueth, D.L. \& Schmitz, A. 2004. The Welfare Economics of Public Policy. A Practical Approach to Project and Policy Evaluation, Edward Elgar, Cheltenham, UK.

10. Lofgren, H., Harris, R.L. \& Robinson S. 2002. A Standard Computable General Equilibrium (CGE) Model in GAMS. International Food Policy Research Institute (IFPRI), Washington D.C.

11. Mardiyah, H., Anindita, R., Hanani, N. \& Koestiono, D. 2014. Impact of Food Import Tariff Decrease in Indonesia. Studia Universitatis Babe-Bolyai Oeconomica, 59(1), 73-87.

12. Markusen, J. \& Rutherford, T. 2004. MPSGE: A User's Guide. Lecture Notes prepared for the UNSW Workshop at February 23-27th, 2004.

13. National Income Policy Center, Fiscal Policy Agency - Indonesian Ministry of Finance. 2011. Kebijakan Restrukturisasi Tarif Bea Keluar Atas Kelapa Sawit, CPO, dan Produk Turunannya. www.fiskal.depkeu.go.id. Downloaded at September 5th, 2013.

14. Novindra. 2011. Dampak Kebijakan Domestik dan Perubahan Faktor Eksternal terhadap Kesejahteraan Produsen dan Konsumen Minyak Sawit di Indonesia. Master Thesis. Bogor Agricultural University, Bogor. Unpublished.

15. Pujiastuti, A.Q., Anindita, R., Hanani, N. \& Kaluge, D. 2013. Changes Effect Of Sugar Import Tariff in Indonesia. Russian Journal of Agricultural and Socio-Economic Sciences, 3(15), 31-38.

16. Sadoulet, E. \& de Janvry, A. 1995. Quantitative Development Policy Analysis. The John Hopkins University Press, Baltimore and London.

17. Salvatore, D. 1997. Ekonomi Internasional. Fifth edition. Erlangga, Jakarta.

18. Shoven, J.B. \& Whalley, J. 1992. Applying General Equilibrium, Cambridge University Press, Cambridge.

19. Thorbecke, E. 2000. The Use of Social Accounting Matrices in Modeling. Paper prepared for The 26th General Conference of the International Association for Research in Income and Wealth in Cracow Polandia at August 27th - September 2nd, 2000. www.stat.gov.pl. Downloaded at August 1st, 2013.

20. Vargas, E.E., Schreiner, D., Tembo, G. \& Marcouiller, D. 1999. Computable General Equilibrium Modeling for Regional Analysis. The Web Book of Regional Science, Regional Research Institute West Virginia University. www.rri.wvu.edu. Downloaded at August 21st, 2013.

21. Varian, H.R. 1992. Microeconomic Analysis. Third edition. W. W. Norton \& Company Inc., New York. 